\title{
Study on antiseptic property of water soluble polyvinyl alcohol building adhesive
}

\author{
Chao Zhu ${ }^{1, a}$, Qing Xiang ${ }^{1, b}$,Xiaoyue Liu ${ }^{1, c}$ and Liming Dong ${ }^{1, d_{*}}$ \\ ${ }^{1}$ School of Chemical Engineering, Xuzhou Institute of Technology, Xuzhou, 221111, China \\ a18361271096@163.com, b15152466547@163.com, ' $18052125714 @ 163 . c o m$, \\ dpolymerdlm@163.com
}

Keywords: PVA, Building adhesive, Preservative

Abstract. With people's strengthened environmental awareness and the decrease of free formaldehyde content in water soluble polyvinyl alcohol (PVA) building adhesive, the problems about mildewing and change of quality in PVA adhesive are getting people's attention. The reasons for the adhesive mildewing were studied on the aspect of PVA adhesive production process. The different dosage of preservatives, such as $\mathrm{CuSO}_{4}, \mathrm{NaNO}_{2}, \mathrm{~A} 26, \mathrm{CP} 19$ and $\mathrm{CN} 46$ which affect on antiseptic properties of adhesive were studied by long-term simulation verified experiment and microorganism infection experiment. The results showed that the antiseptic properties of PVA adhesives were affected by different species and dosage of preservatives. The isothiazolone derivatives such as A26, CP19 and CN46 had better antiseptic properties and compatibility than $\mathrm{CuSO}_{4}$ and $\mathrm{NaNO}_{2}$. Research shows that CN46 has optimal and long-term antiseptic effect when its amount was $0.25 \%$.

\section{Introduction}

PVA of water-soluble polymer has been widely used in the fields of building adhesive field for its good adhesion [1,2]. However, PVA often needs to be modified through increasing the degree of acetalation due to the poor flowability and water resistance in high solid content. For instance, ‘107 Adhesives', which is a better performance, low price and easy installation adhesive, is a product firstly prepared by PVA and formaldehyde in acidic conditions[3,4]. For the some reason, the inadequate acetalization reaction results to the high content of free formaldehyde in adhesive products. Formaldehyde vapor would greatly stimulate the respiratory and eye system and have a role of strong carcinogenic and promoting cancer. Many scholars had studied on the methods of decreasing the content of formaldehyde in adhesive [5-8]. The release of free formaldehyde in water soluble polyvinyl alcohol building adhesive was stick limited in JC/T438-2006, which limits formaldehyde pollution concentration amount for $\leqslant 1 \mathrm{~g} / \mathrm{kg}[9]$.

With the decrease of formaldehyde, the storage of product was rapidly shortened so that the problems about mildewing and change of quality in PVA adhesive occurred even in two months in summer. Actually, formaldehyde is a kind of rapid broad-spectrum preservative in gas phase conditions especially, free formaldehyde in adhesive inhibit the propagation of microorganism. In this paper, the reasons for the adhesive mildewing were studied on the aspect of PVA adhesive production process. The problem of PVA adhesive stored for age was mainly studied via adding different species and amounts of preservatives into adhesive to contrast the effects of antiseptic properties and compatibility.

\section{Experimental}

Materials. The PVA building adhesive was obtained from Jiangsu qiyanli adhesive Co.Ltd. The solid conten was $8 \%$, the free formaldehyde content was $0.2 \mathrm{~g} / \mathrm{Kg}$. the CuSO 4 and $\mathrm{NaNO} 2$ was gifted by Shanghai suyi Chemical reagent. Ltd, AR China. A26 was obtained from Germany Schülke \& Mayr Co., Ltd., effective content 2\%; CP19 and CN46 were obtained from Germany hofmann Co., Ltd., effective content $2.5 \%$ and $3 \%$, respectively. 
Performance Testing. The long-time verification test is designed in order to simulate summer high fever and high wet condition. The 500g of PVA adhesive sample were separately added into the five preservatives which mass content is $0.2 \%$. It was stirred and mixed well in airtight plastic bottles, stored on the condition of $37^{\circ} \mathrm{C}$ temperature and $78 \%$ relative humidity. The mildew situations of samples were observed during 90 days.

Microorganism infection experiment is designed. The $100 \mathrm{~g}$ of PVA adhesive sample were separately added into the five preservatives which mass content is $0.2 \%$ (and different amount of CN46 preservative). It was stirred and mixed well in culture dishes. The $1 \mathrm{ml}$ of microorganism mixture liquid are separately coated uniform on the surface of blank sample (not contain preservatives) and the above prepared samples to carry out microorganism infection experimental for once a week, continuous operation of 6 weeks. The mixed Microorganism liquid includes bacteria, mould, yeast and a dominant strain, inoculated-pathogen quantities of each microorganism were above $10^{8} \mathrm{cfu} / \mathrm{g}$. As shown in Table 1 the inoculated-pathogen kinds and quantities.

Table1 the inoculated-pathogen kinds and quantities $\left(\times 10^{8} \mathrm{cfu} / \mathrm{mL}\right)$

\begin{tabular}{|c|c|c|c|c|c|c|c|}
\hline $\begin{array}{l}\text { inoculated-pathogen } \\
\text { kinds }\end{array}$ & ATCC & $\begin{array}{l}\text { First } \\
\text { week }\end{array}$ & $\begin{array}{l}\text { Second } \\
\text { week }\end{array}$ & $\begin{array}{l}\text { Third } \\
\text { week }\end{array}$ & $\begin{array}{c}\text { Fourth } \\
\text { week }\end{array}$ & $\begin{array}{l}\text { Fifth } \\
\text { week }\end{array}$ & $\begin{array}{l}\text { Sixth } \\
\text { week }\end{array}$ \\
\hline Escherichia coli & 8739 & 1.4 & 1.2 & 1.1 & 1.1 & 1.0 & 1.5 \\
\hline Pseudomonas aeruginosa & 9027 & 1.3 & 1.0 & 1.4 & 1.3 & 1.2 & 1.4 \\
\hline Staphylococcus aureus & 6538 & 1.1 & 1.7 & 1.2 & 1.2 & 1.4 & 1.3 \\
\hline $\begin{array}{l}\text { Pseudomonas } \\
\text { flourescens }\end{array}$ & 17397 & 1.2 & 1.1 & 1.3 & 1.5 & 1.7 & 1.1 \\
\hline Klebsiella pneumoniae & 4352 & 1.7 & 1.3 & 1.5 & 1.1 & 1.4 & 1.2 \\
\hline Candida albicans & 10231 & 1.5 & 1.6 & 1.4 & 1.2 & 1.5 & 1.3 \\
\hline Aspergillus niger & 16404 & 1.4 & 1.1 & 1.2 & 1.5 & 1.1 & 1.7 \\
\hline Penicillium funiculosum & 36839 & 1.6 & 1.2 & 1.1 & 1.3 & 1.2 & 1.7 \\
\hline
\end{tabular}

The test condition of relative humidity were above $85 \%$, the temperature was $35^{\circ} \mathrm{C}$ in the first three days, and $28^{\circ} \mathrm{C}$ in the after four days. The microbial contents in samples are detected in 2 and 7 days after each inoculation. If the microorganism content in the sample is less than $10^{3} \mathrm{cfu} / \mathrm{g}$, the sample can be regard as pass the microbial challenge tests; if the microorganism content in the sample is above $10^{3} \mathrm{cfu} / \mathrm{g}$ in two weeks continuous, then the sample can be regard as not pass the microbial challenge tests.

\section{Results and discussion}

The reason of analysis adhesive mildewing. The production process of PVA building adhesive is shown in Figure 1. The reaction condition of PVA is the wicked Microorganism survival condition for the strong acid $(\mathrm{pH}=1-2)$, higher temperature $\left(>90^{\circ} \mathrm{C}\right)$ and higher concentration formaldehyde. However, the reactants need to be adjustment the content of mass by supplement water again.

The microbiological analysis of reactants and supplement water were developed, which shows that microorganism could not survive in condition of high temperature, strong acid and high concentration formaldehyde. The total viable count of water bacteria detection was $5 \mathrm{cfu} / \mathrm{mL}$, though that value is not high, and it also could be the reason of inducement mildew and metamorphic during product storage. The microorganism infection experiments were carried out in the adhesive of not adding any preservatives by using bacteria, yeast and mould. The results were shown that yeast and mould have not been detected and only bacteria appeared large propagation. It also illustrates that bacteria is the main cause of adhesive metamorphic. The bacteria detection results were $2.1 \times 10^{3} \mathrm{cfu} / \mathrm{mL}$ in the second day, and $2.5 \times 10^{5} \mathrm{cfu} / \mathrm{mL}$ in the seventh day, which illustrate that residues formaldehyde $(0.2 \mathrm{~g} / \mathrm{Kg})$ can not control the growth of bacteria in the condition of not adding any preservatives, and bacteria appears rapid propagation eventually leading to problems of products surface discoloration, fluidity variation, mildew and stink. 


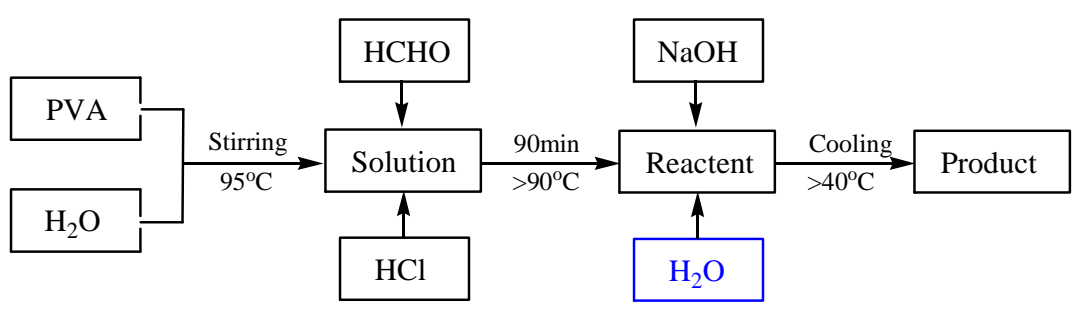

Fig.1 The production process of PVA building adhesive

Long-term simulation verification experiment. The problems about mildewing and change of quality in PVA adhesive mainly concentrated in the summer. So it is simple and intuitive design method that simulation summer environment is designed to the high fever and high wet condition. After the mildew situations of samples were observed during 90 days, all samples have not been appeared any mildew and metamorphic phenomena, which illustrate that five kinds of preservatives all have certain bacteriostasis effect. It has been found experimentally that flocky precipitates appeared at the bottom of the sample separately adding into $\mathrm{CuSO}_{4}$ and $\mathrm{NaNO}_{2}$. It might be the complex product of ions and large molecules PVA, which affect not only products appearance state but also products adhesive effect. Therefore, $\mathrm{CuSO}_{4}$ and $\mathrm{NaNO}_{2}$ should be avoided to be preservative of PVA for compatibility. There are no significantly state changes and better compatibility with PVA in the samples respectively adding preservatives of A26, CP19 and CN46.

The effect of different preservative. Microorganism infection experiment is to simulate the environmental state of microorganism continuous increasing, which were more extreme conditions on the investigation to the preservatives. The Fig 2 is bacteria detection results after the inoculation of microorganism infection experiment at the second day every week; it shows more the sterilization effect of preservatives to infection bacteria. The Fig 3 is bacteria detection results after the inoculation of microorganism infection experiment at the seventh day every week; it shows more the bacteriostasis effect of preservatives to infection bacteria. As the Fig 2 shows that five kinds of preservatives all have certain sterilization effect and ability appeared varying degrees of decline as the experimental progress in weeks. The sterilization effect of five preservatives is obviously CN46 > $\mathrm{CP} 19>\mathrm{A}_{26}>\mathrm{CuSO}_{4}>\mathrm{NaNO}_{2}$. The experimental data of the first week is $7.8 \times 10^{2} \mathrm{cfu} / \mathrm{mL}, 9.2 \times 10^{2}$ $\mathrm{cfu} / \mathrm{mL}$ respectively. It was shown that the sterilization effect of $\mathrm{CuSO} 4$ and NaNO2 is poor and the samples only passed the challenge test $\left(<10^{3} \mathrm{cfu} / \mathrm{mL}\right)$ in the first week, contrast with the date of blank test $\left(2.1 \times 10^{3} \mathrm{cfu} / \mathrm{mL}\right)$, the two preservatives effect were not obvious. Studies have shown that copper ion in $\mathrm{CuSO}_{4}$ is the main reason to sterilization and it will be into the pathogen cells to force protein to solidify or degenerate, reaction of copper ion and -SH in pathogen cells is to damage it's enzyme action, and even reaction of cation on cell surface play replacement action[10]. $\mathrm{NO}_{2}$ and $\mathrm{NO}$ were formed from nitrite ion in $\mathrm{NaNO}_{2}$ under the action of bacteria and tissue reducing substances, which is the main factor for sterilization. $\mathrm{NO}_{2}$ and $\mathrm{NO}$ will inhibit Fe-S protein and energy metabolism and will inhibit DNA and gene expression and will inhibit the growth of cell wall and membrane [11]. Because nitrite ions need to form $\mathrm{NO}_{2}$ and $\mathrm{NO}$ firstly, its bactericidal ability is weaker than $\mathrm{CuSO}_{4}$. The sample containing A26 preservative, which has a spot of bacterial community $(58 \mathrm{cfu} / \mathrm{mL}$ and $172 \mathrm{cfu} / \mathrm{mL}$ respectively) in the first two days, passed the challenge test, however the bacterial community increased rapidly from the beginning third week. The samples containing CP19 and CN46 preservatives, which did not detect any bacterial community in the first three weeks, and a spot of bacterial community was detected in the fourth and fifth week but the test results is $<10^{3} \mathrm{cfu} / \mathrm{mL}$, passed the challenge test and bacterial community tend to increase rapidly from the beginning sixth week. All of A26, CP19 and CN46 belong to the isothiazolone derivatives. The main sterilization composition of them are aqueous dispersion with 2-methyl-3(2H)-isothiazolone (MIT) and 5-Chloro-2-methyl-3(2H)-isothiazolone (CMIT). The content of MIT and CMIT is only 2\% in aqueous dispersion and need less amount compared with $\mathrm{CuSO}_{4}$ and $\mathrm{NaNO}_{2}$, which shows that preservatives effect were very obvious. The isothiazolone derivatives form disulfide bond with -SH in cysteine of protein depending on S-N on it's heterocycle to make the protein deactivation and reach bactericidal objective. There are also studies suggest that the derivative class compounds of isothiazolone derivatives enter the cell and form chlorine bond with base in cells nucleic acid to make 
the nucleic acid not to replicate and transcript and then make bacteria death to reach bactericidal objective [12].

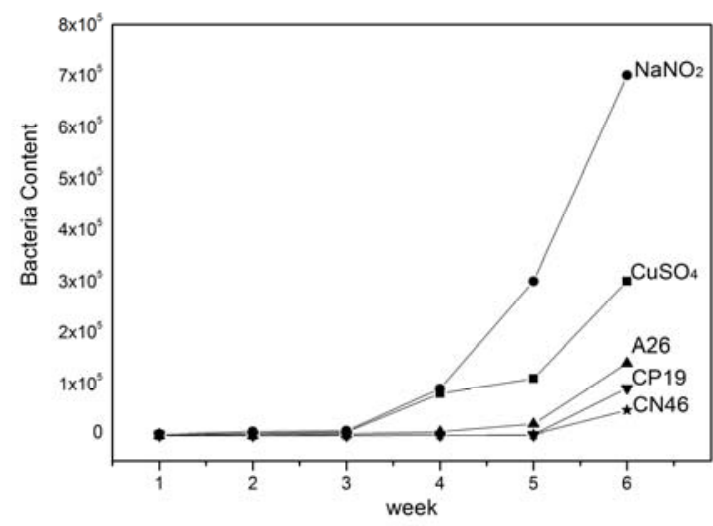

Fig. 2 The bacteria test results of 2th day microorganism infection experiment

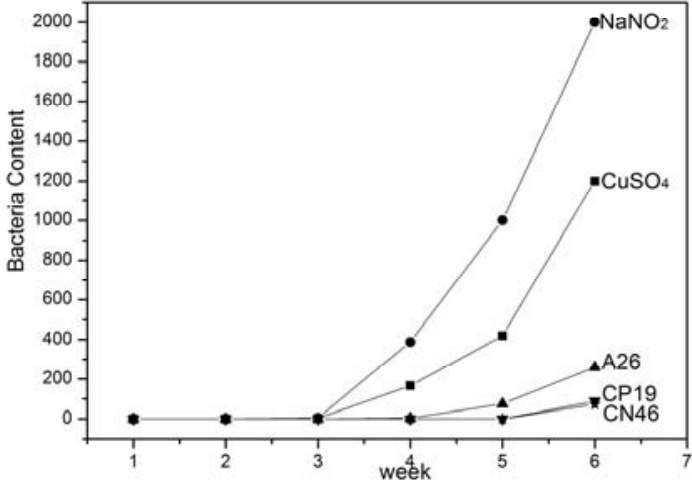

Fig. 3 The bacteria test results of 7th day microorganism infection experiment

By contrast with Fig. 2 and Fig. 3 that the bacterial number decreased significantly with the prolonging of time in the same week. Never bacterial community were detected in the samples with all preservatives at first two weeks, which shows that five kind preservatives all have sustainable ability of sterilization and bacteriostasis activity. As the Fig 2 shows that five kinds of preservatives all have certain bacteriostasis effect and ability appeared varying degrees of decline as the experimental progress in weeks. The bacteriostasis effect of five preservatives was CN46 > $\mathrm{CP} 19>\mathrm{A} 26>\mathrm{CuSO}_{4}>\mathrm{NaNO}_{2}$, and the trend of decreasing is as same as the sterilization effect. Few bacterial communities were detected in the samples with $\mathrm{CuSO}_{4}$ and $\mathrm{NaNO}_{2}$ at the first three week, and bacteria grow rapidly later. The number of bacteria communities was more than $1 \times 10^{3} \mathrm{cfu} / \mathrm{mL}$ and failed in challenge in the samples with $\mathrm{NaNO}_{2}$ at fifth week and $\mathrm{CuSO}_{4}$ at sixth week. A26, CP19 and CN46 passed the challenge test succeed in the six week successfully, and the number of bacteria community in the samples with CN46was $73 \mathrm{cfu} / \mathrm{mL}$, so CN46 was regard as the optimal preservative. The content of MIT and CMIT is 2\% in A26, 2.5\% in CP19, and 3\% in CN46, which shows that the bacteriostasis effect is more obvious with the increasing of effective material content (MIT and CMIT).

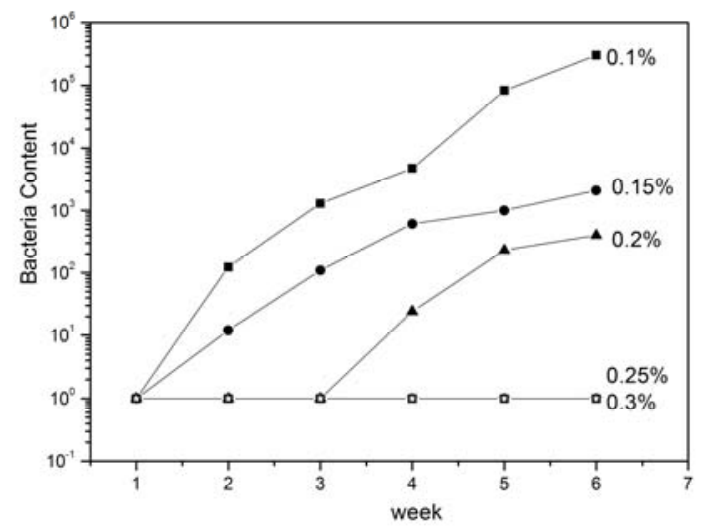

Fig 4 The bacteria test results of 2th day with content of CN46

The effect of content of CN46. Through the comparative analysis of five kinds of preservatives, sterilization and bacteriostasis effect of CN46 were best and the price of CN46 is cheap. Therefore, microorganism infection experiments about different content of CN46 preservative were done and the bacteria detection results of infection experiments were shown in Fig 4. The results show that the sterilization effect presents the tendency of reduction afterwards with the decrease of CN46 content.The growth of bacteria was inhibited at the first week but bacteria increased clearly from the 
second week when the content of CN46 is $0.1 \%$ and $0.15 \%$; the growth of bacteria was inhibited in the first three weeks but bacteria increased clearly from the fouth week when the content of CN46 is $0.2 \%$; bacteria was not inhibited until sixth week when the content of CN46 is above $0.25 \%$, so the optimal selection preservative of adhesive is CN46 and its amount should reach $0.25 \%$ or more.

\section{Conclusion}

The reasons for the adhesive mildewing comes from the introduce bacteria of supplement water after the acetalation process. Residues formaldehyde $(0.2 \mathrm{~g} / \mathrm{Kg})$ can not control the growth of bacteria in the high fever and high wet condition. it is necessary to add preservatives for the PVA adhesive long term storage. It has been found experimentally that $\mathrm{CuSO}_{4}$ and $\mathrm{NaNO}_{2}$ will produce flocky precipitates with PVA, which affects the quality of adhesive and compatibility. The sterilization and bacteriostasis effect of five preservatives is obviously CN46 $>\mathrm{CP} 19>\mathrm{A}_{2} 6>\mathrm{CuSO}_{4}>\mathrm{NaNO}_{2}$. The preservatives containing isothiazolone derivatives had better antiseptic properties and the effect is better with the increase of effective substance content. Research shows that CN46 has optimal and long-term antiseptic effect when its amount was $0.25 \%$, which prolong the shelf life of the adhesive products.

\section{Acknowledgements}

The project was supported by the Natural Science Foundation of Jiangsu Province (No. BK2012142)

\section{References}

[1] C.A. Finch, Polyvinyl alcohol; properties and applications[M]. John Wiley \& Sons, 1973.

[2] R.X.Yan, Water-soluble polymer(the second edition) [M]. Chemical industry press, 2010.

[3] F. Xu, Production and modification techniques of 107 adensive[J]. China adhesives, 1994, 3(6): 24-27.

[4] J.Ch. Liu, Discussion on the control of reaction mechanism, improving the viscosity and storage period of 107 adensive[J]. Chemical building materials, 1989, 5: 18-22.

[5] L.H. Zhu, C.W. Zhang, Y.J. Tang etc. Study on the methods to reduce the free formaldehyde content in polyvinyl formal adhesive[J]. Journal of Functional Materials, 2010, 11: 007.

[6] Sh.Yang, X.F. Wang, Synthetic conditions of polyvinyl formal adhesive optimized by orthogonal experiment method[J]. China adhesives, 2013, 22(8): 10-13.

[7] H.Sh. Chen, D.H. You, A study on a novel technique for producing PVF adhesive[J]. Journal of Ningde Teachers College(Natural Science), 2005, 7(3).

[8] G.X. Li, Redueing the content of free aldehyde in 107 Glue which caused by additive Reaetion nitric derivatives react on hydroxyl[J]. Peckaging engineering, 1996, 17(6): 33-35.

[9] JC/T 438-2006. Water-soluble polyvinyl alcohol building adhesive, The national development and Reform Commission of the people's Republic of China, 2006.

[10] W.J. Wu, The principle of Chinese agriculture[M]. Agriculture Press, Peking, 2000, 8: 188-214

[11] Q.Li. Dong, Tu Kang. Advanced research on mechanisms of nitrite inhibition of bacteria in cured meat[J]. Progress in Modern Biomedicine, 2006, 6(3): 48-52.

[12] J.T. Wang, Studies on the bacteriostatic activity of isothiazolone derivatives[D]. DalianUniversity of Technology, 2013. 